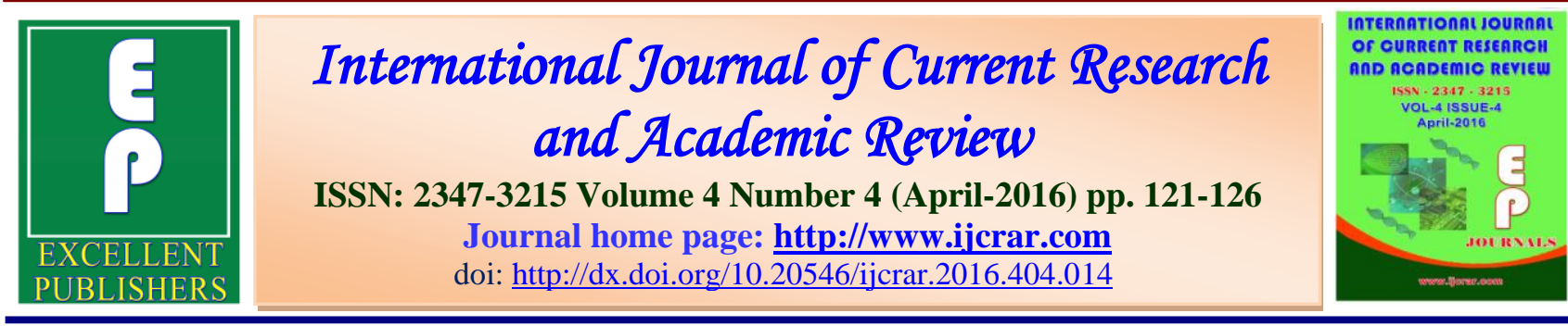

\title{
Proximate Composition of the Four Acacia Taxa Seeds in Central Sudan
}

\author{
Eiman Mohammed Ali Mustafa* and Hatil Hashim Al-Kamali
}

Department of Botany, Faculty of Science and Technology, Omdurman Islamic University, Omdurman, Sudan

*Corresponding author

\begin{tabular}{|c|c|}
\hline KEYWORDS & $A B S T R A C T$ \\
\hline $\begin{array}{l}\text { Acacia } \\
\text { Taxa Seeds, } \\
\text { Composition, } \\
\text { central and } \\
\text { western Sudan }\end{array}$ & $\begin{array}{l}\text { The aim of this study was to evaluate the proximate composition and mineral } \\
\text { content of mature seeds of four acacias taxa grown in central and western } \\
\text { Sudan (A.nilotica ssp. adansonia, A.nilotica ssp. nilotica, A. seyal var. seyal } \\
\text { and A. sieberiana var. sieberiana). The composition of the seeds moisture, } \\
\text { ash, fat, protein, fiber and carbohydrate were expressed as follow. Moisture } \\
\text { content ranged between } 5.94 \text { to } 6.37 \% \text { for A.seyal var. seyal and A. nilotica } \\
\text { ssp. adansonia, respectively. Whereas, ash content varied from } 4.02 \text { to } 4.94 \\
\% \text { for A. sieberiana var. sieberiana and A.seyal var. seyal,respectively. Fat } \\
\text { content ranged between } 4.09 \% \text { for A.seyal var. seyal to } 7.78 \% \text { A. sieberiana } \\
\text { var. sieberiana. Protein content varied from } 20.22 \text { to } 26.44 \% \text { for A. nilotica } \\
\text { ssp. adansonia and A.seyal var. seyal, respectively. Whereas, fiber content } \\
\text { value ranged from } 22.42 \% \text { for A.seyal var. seyal to } 32.74 \% \text { for A. nilotica } \\
\text { ssp. adansonia. Carbohydrate content ranged from } 30.76 \% \text { to } 40.77 \% \text { for } A \text {. } \\
\text { nilotica ssp. Adansonia and A. sieberiana var. sieberiana, respectively. } \\
\text { Obviously in four Acacias the contents of the some trace and essential } \\
\text { mineral elements are low in comparison by others seeds studied in others } \\
\text { countries. The values range of copper, zinc, chromium, lead, manganese and } \\
\text { iron elements in four acacias seeds were copper between } 4.65 \text { to } 7.56 \mu \\
/ 100 \text { gm, zinc between } 27.75 \text { to } 47.52 \mu / 100 \text { gm, chromium between } 0.67 \text { to } \\
1.32 \mu / 100 \text { gm, lead between } 0.00 \text { to } 0.08 \mu / 100 \text { gm, manganese } 8.54 \text { to } 42.06 \\
\mu / 100 \text { gm and iron between } 9.26 \text { to } 89.98 \mu / 100 \text { gm. Hence, concluded that } \\
\text { high amount of protein, fiber and moderate amount from carbohydrate } \\
\text { encourage utilizing acacias seed as livestock fodder. }\end{array}$ \\
\hline
\end{tabular}

\section{Introduction}

Acacia is the most significant genus of the subfamily Mimosoideae. It is estimated that there are roughly 1380 species of Acacia worldwide, about two-third of them native to Australia and rest spread around tropical and subtropical regions of the world (Saini et al, 2008). Acacia seyal is usually found near riverbeds at lowland sites and near 
water holes or seasonally flooded black cotton soils. Large herbivores may play an important role in seeds dispersal (Razanamandranto et al., 2004).

Acacia is effective when used as a coating on pills to make the bitterness easier to swallow or digest. It is important to the food industry as a flavor fixative and emulsifier. This plant has been used in traditional medicine to treat high cholesterol, diabetes, cancer, gingivitis, mouth sores, pharyngitis, and indigestion in children (Troup, 1983). Fodder for livestock in Sudan, as in developing countries, suffers from protein deficiency, which is attributed to the lack of forage (Azim et al., 2011).

In addition to its fodder's nutritional values for the livestock, Acacia seyal has additional various benefits. Acacia seyalis essential for adding natural fertilizers to the soil through symbiotic association with compatible rhizobia and mycorrhizal fungi (Dommergues, 1995; Fall et al., 2009). In addition, Acaicaseyalis used for gum production, which is commercially known gum Talha. It is also an important source of fuel-wood and charcoal (Mohammed and Röhle, 2011). Furthermore, in the arid and semiarid zones, crude protein content in forage is poor, which is the major limiting factor for livestock's production. This issue increases the cost of conventional protein supplements for livestock particularly for ruminants, which leads to the loss of weights and high mortality rates especially among the young and poorly fed pregnant females (Babiker and Mohamed, 2003).

Acacia species, in general, recorded such medicinal benefits as antidiabetes (Babiker, I. A. and Mohamed et al., 2013), antimicrobial (Babiker, I. A. and Mohamed et al., 2012), anti-bacterial (Olajuyigbe and Afolayan, 2012), antimalarial (Okokon et al., 2010), and anti-inflammatory activities
(Adedapo et al., 2008), besides gastrointestial and respiratory activities (Imran et al., 2011). (N R C, 1978)Reported that Acacia seyal var seyal leaves have a crude protein content $(34.6 \%)$, crude fiber $(16.2 \%)$ and have deficiency in Sodium, Potassium, Phosphorus, Zinc, Manganese, Iron and Copper.

The objectives of this study was focus on: to evaluate the nutritive value of four acacias and determination the percentage of minerals content, because these acacias have high amount of protein and fiber and reasonable amount of carbohydrate.

\section{Materials and Methods}

\section{Materials}

Acacia seeds (4 taxa): A cacianilotica ssp. adansonia, A.niloticasspnilotica, A. seyal var seyal and A. sieberiana var sieberiana. The voucher specimens are kept at Herbarium of Botany Department, Faculty of Science and Technology, Omdurman Islamic University. The identification of the studied taxa was done according to (ALAmin, 1990). The taxa under investigation were brought from Soba Research Centre, Khartoum.

\section{Seeds Collection}

The taxa under investigation were brought from Soba Research Centre, Khartoum. Seeds were collected from various areas of central Sudan. These seeds were identified by the plant taxonomist of Soba Research Forests,Ustaz Hassan Al-Bager, Ministry of Science and Technology, Khartoum.

\section{Methods}

\section{Proximate Composition}

The determination of moisture, ash, fat and fiber contents were carried out on the 
candidate Acacia samples according to (A. A. C. C, 2000) methods. Whereas, crude protein content of candidate Acacia taxa was carried out according to (AOAC, 1984) methods. The total carbohydrates content were calculated carried out by difference. The sum of moisture, fat, protein and ash contents was subtracted from 100 as it was described by (West et al., 1988).Minerals of fourth acacia taxa samples were extracted according to Pearson's method.

\section{Samples Preparation for Proximate Composition}

Investigated seeds sample were cleaned from dust and foreign matter, then were milled into fine flour to further analysis (proximate composition, and mineral content)

\section{Results and Discussion}

\section{Proximate Composition}

Table (1) showed that moisture content values of four acacia taxa seeds ranged from $5.94 \%$ to $6.37 \%$. A. nilotica ssp. adansonia gained the highest value $6.37 \%$ compared with other acacia studied. Whereas, A. seyal var seyal obtained the lowest value $5.94 \%$. Ash content of acacia taxa values ranged between 4.02 to $4.96 \%$. These results Similar to those obtained by who stated that ash content in acacia seeds was $4.55 \%$ these results indicated that higher minerals content. While fat content of four acacia taxa ranged between $4.09 \%$ to 7.78 $\%$.These results were higher than the results obtained by who mentioned that lipid content was lower in pod (5.03 and $4.75 \%)$ than in seeds. The proximate composition of plants and crops seeds varies depending on the cultivars, climatological condition, and maturity and collection time of seeds. Water and fertilizer application as well as acceptability, selectivity and intake of nutrients by plants and crops (Zia-UL-Haq et al., 2011). The results indicated that protein content values of four acacia seeds ranged between 20.22 to $26.44 \%$. Highest value noted in acacia seyal var seyal, flowed by acacia sieberiana var. seiberiana, acacia nilotica ssp. nilotica and the lowest value obtained by acacia nilotica ssp. adansonia.This is an indication that these acacias seed scan be grouped as a part of plants rich legume seeds.

Table.1 Proximate Composition of Four Acacia Seeds Taxa

\begin{tabular}{|c|c|c|c|c|c|c|}
\hline Acacia taxa & $\begin{array}{c}\text { Moisture } \\
\%\end{array}$ & $\begin{array}{l}\text { Ash } \\
\%\end{array}$ & $\begin{array}{l}\text { Fat } \\
\%\end{array}$ & $\begin{array}{c}\text { Protein } \\
\%\end{array}$ & $\begin{array}{c}\text { Fibre } \\
\%\end{array}$ & $\begin{array}{c}\text { Carbohydrats } \\
\%\end{array}$ \\
\hline $\begin{array}{c}\text { Acacia nilotica ssp. } \\
\text { Adansonia }\end{array}$ & $\begin{array}{c}6.37 \\
\pm 0.39\end{array}$ & $\begin{array}{c}4.40 \\
\pm 0.20\end{array}$ & $\begin{array}{c}5.52 \\
\pm 0.07\end{array}$ & $\begin{array}{l}20.22 \\
\pm 0.63\end{array}$ & $\begin{array}{l}32.74 \\
\pm 0.14\end{array}$ & $30.76 \pm 0.71$ \\
\hline $\begin{array}{c}\text { Acacia nilotica ssp. } \\
\text { Nilotica }\end{array}$ & $\begin{array}{c}6.06 \\
\pm 0.07\end{array}$ & $\begin{array}{l}4.45 \\
\pm 0.1\end{array}$ & $\begin{array}{c}5.41 \\
\pm 0.07\end{array}$ & $\begin{array}{l}20.51 \\
\pm 0.62\end{array}$ & $\begin{array}{l}26.66 \\
\pm 1.03\end{array}$ & $36.92 \pm 0.83$ \\
\hline Acacia seyal var. seyal & $\begin{array}{c}5.94 \\
\pm 0.00\end{array}$ & $\begin{array}{r}4.96 \\
\pm 0.22\end{array}$ & $\begin{array}{c}7.78 \\
\pm 0.59\end{array}$ & $\begin{array}{l}26.44 \\
\pm 0.62\end{array}$ & $\begin{array}{l}22.42 \\
\pm 0.10\end{array}$ & $32.46 \pm 0.85$ \\
\hline $\begin{array}{c}\text { Acacia sieberianavar. } \\
\text { sieberiana }\end{array}$ & $\begin{array}{c}6.28 \\
\pm 0.08\end{array}$ & $\begin{array}{r}4.02 \\
\pm 0.14\end{array}$ & $\begin{array}{l}4.09 \\
\pm 0.19\end{array}$ & $\begin{array}{l}21.66 \\
\pm 0.65\end{array}$ & $\begin{array}{l}22.88 \\
\pm 0.14\end{array}$ & $40.77 \pm 1.06$ \\
\hline
\end{tabular}


Int.J.Curr.Res.Aca.Rev.2016; 4(4): 121-126

Table. 2 Minerals Content in Four Acacia Seeds Taxa $\mu / 100 g m$

\begin{tabular}{|c|c|c|c|c|c|c|}
\hline \multicolumn{1}{|c|}{ Acacia taxa } & $\mathrm{Cu}$ & $\mathrm{Zn}$ & $\mathrm{Cr}$ & $\mathrm{Pb}$ & $\mathrm{Mn}$ & $\mathrm{Fe}$ \\
\hline Acacia nilotica ssp. adansonia & 4.97 & 29.94 & 1.32 & 0.00 & 38.28 & 9.26 \\
\hline Acacia nilotica ssp. nilotica & 7.56 & 33.54 & 0.94 & 0.03 & 42.06 & 39.87 \\
\hline Acacia seyal var. seyal & 6.03 & 47.52 & 0.67 & 0.08 & 18.33 & 89.98 \\
\hline Acacia sieberiana var. sieberiana & 4.65 & 27.75 & 1.10 & 0.00 & 8.54 & 12.31 \\
\hline
\end{tabular}

The most interesting value is that of protein content which is considered high. Fiber content of the present samples studied ranged from $22.42 \%$ to $32.74 \%$. These results were in agreement with who stated that fiber content was found in seed $6.70 \%$. Carbohydrates content ranged from $30.76 \%$ to $40.77 \%$, these values obtained were lower than the value observed by Zia-UL-Haq et al., 2011. Who stated that carbohydrates content of acacia seed was $52.30 \%$.

\section{Mineral Content}

The main content of trace and essential mineral element $(\mu / 100 \mathrm{gms} \mathrm{DW})$ in the mature dry seed of fourth acacia samples are shown in table (2). The order depending on the contents of elements $\mu / 100 \mathrm{gm}$ in four acacia seeds samples in sudan studied were $\mathrm{Cu}, \mathrm{Zn}, \mathrm{Cr}, \mathrm{Pb}, \mathrm{Mn}$ and $\mathrm{Fe}$. Copper content of four acacia seeds ranged from 4.65 $\mu / 100 \mathrm{gm}$ for A. sieberiana $\operatorname{var}$ sieberiana to $7.56 \mu / 100 \mathrm{gm}$ for A. nilotica ssp. Adansonia. Zinc element content was found to be between 27.75 for A. sieberiana var sieberiana to $47.52 \mu / 100 \mathrm{gm}$ for A.seyalvar seyal. The results appeared that $\mathrm{Cr}$ and $\mathrm{Pb}$ elements values considered the lowest values among the sample investigated. The Mn element seemed to be slightly high in A. nilotica ssp.Nilotica 42.06 $\mu / 100 \mathrm{gm}$ followed by nilotica ssp. Adansonia38.38 $\mu / 100 \mathrm{gm}$. Fe element was found to be very high in A.seya lvar seyal.(89.98 $\mu / 100 \mathrm{gm})$ whereas, the lowest value obtained by A. nilotica ssp. Adansonia (9.26 $\mu / 100 \mathrm{gm})$. Minerals help maintain acid-base balance, to keep the body $\mathrm{pH}$ neutral (3). Minerals help regulate body processes, such as in enzyme systems. They also function in nerve impulse transmission and muscle contraction.

\section{Conclusion and Recommendation}

The result of this work shows that Acacia nilotica ssp. adansonia, A.niloticas spnilotica, $A$. seyalvarseyal and $A$. sieberiana var sieberiana could be an important trees crop in Sudan region (economically and nutritionally). It has relatively an average mineral content and rich in protein content which can serve to reduce the protein shortage in the region.

Base on our findings we recommend the following:-

There is a growing concern about human destruction of vegetation, it is necessary to collect the germplasm of this untapped nutritive and economically important tree species for conservation before it becomes extinct. The seeds should be incorporated in agricultural development programmes placing special emphasis on its nutritional value and production potential.

\section{References}

A.A.C.C. 2000. Approved Methods of American Association of Cereal Chem., $10^{\text {th }}$ ed., St. Paul, MN., USA. Adedapo, A. A., Sofidiya, M.O., Masika, P.J., Afolayan, A.J. 2008. 
Int.J.Curr.Res.Aca.Rev.2016; 4(4): 121-126

Anti-inflammatory and Analgesic Activities of the Aqueous Extract of Acacia karroo Stem Bark in Experimental Animals." Basic and Clin. Pharmacol. Toxicol., 103: 397-400.

Akpanyung, E.O. 2005. Proximate and mineral composition of bouillon cubes produced in Nigeria. Pakistan J. Nutrition, 4: 327-329.

AL- Amin, H.A. 1990. Trees and Shrubs of the Sudan. Ithaca press.484p.

AOAC. 1984. Official Method of Analysis $14^{\text {th }}$ ed. Association. Agric. Chem., Washington D. C.

Azim, A., Ghazanfar, G., Latif, A., Nadeem, M.A. 2011. "Nutritional Evaluation of Some Top Fodder Tree Leaves and Shrubs of District Chakwal, Pakistan in Relation to Ruminants Requirements. Pakistan J. Nutrition, 10: 54-59.

Babiker, I.A., Mohamed, T.A. 2003. "Use of Leucaena leucocephala Leaves as Protein Supplement in Sheep Diets." Sudan J. Animal

Production, 16: 39-46.

Bino Kingsley, R., Jesuraj, S.A.V., Brindha, P., Subramoniam, A., Atif, M. 2013. Anti-diabetes Activity of Acacia farnesiana (L.) WilldinAlloxan Diabetic Rats. Int. J. Pharm. Tech. Res., 5: 112-118.

Dommergues, Y.R. 1995. "Nitrogen Fixation by Trees in Relation to Soil Nitrogen Economy." Nutrient Cycling in Agroecosystems 42: 215-230.

Fall, D., Diouf, D., Neyra, M., Diouf, O., Diallo, N. $2009 . \quad$ Physiological and Biochemical Responses of Acacia seyal (Del.) Seedlings under Salt Stress Conditions. J. Plant Nutrition, 32: 1122-1136.

Imran, I., Hussain, L., Zia-Ul-Haq, M., Gilani, A.H., De Feo, V. 2011.
"Gastrointestial and Respiratory Activities of Acacia leucophloea" J. Ethnopharmacol., 138: 676-682.

Mohammed, M.H., Röhle, H. 2011. Evaluation of Height Functions for Acacia seyalDel. Variety Seyal in Natural Stands, South Kordofan Sudan. Int. J. Sustainable Agri., 3:88-96.

NRC. 1978. Nutrient requirement of domestic animals, No. 3.Nutrient requirement per dairy cattle. Nat. Acad.Sci., National Research Council, Washington D.c.

Okokon, J.E., Obot, J., Opara, K.N., Etim, E. 2010. "In Vivo Antimalarial Activity of Ethanolic Leaf Extract of Acacia auriculiformis. Int. J. Drug Development and Res., 2: 482-487.

Olajuyigbe, O.O., Afolayan, A.J. 2012. "Synergistic Interactions of MethanolicExtract of Acacia mearnsii De Wild. With Antibiotics against Bacteria of Clinical Relevance. Int. J. Mol. Sci., 13: 8915-8932.

Pearson, D. 1981. Pearson Chemical Analysis of Food, edn. By Egon, H.; Kirk, R.; Sawyer, R., $8^{\text {th }}$ edition, Churchill-Livingstone-London, New York.

Pradeep, A.R., Agarwal, E., Bajaj, P., Shanbhag, N., Uma, S.R. 2012.

Document Clinical and Microbiologic Effects of Commercially Available Gel and Powder Containing Acacia arabicaon Gingivitis. Australian Dent. J., 57:312-318.

Razanamandranto, S., Tigabu, M., Neya, S., Oden, P.C. 2004. "Effects of Gut Treatment on Recovery and Germinability of Bovine and Ovine Ingested Seeds of Four Woody Species from the Sudanian Savanna 
in West Africa. Flora (Jena).” 199: 389-39.

Saini, M.L., Saini, R., Roy, S., Kumar, A. 2008. Comparative pharmacognostical and antimicrobial studies of acacia species (Mimosaceae). J. Med. Plants Res., 12: 378-386.

Troup, R.S. 1983. Troup's silviculture of Indian trees, 4. Leguminosae.Forest Research Institute and Colleges, Dehra Dun, India.
West, C.E., Repping, F., Temalilwa, C.R. 1988. Handbook on the composition of food commonly eaten in East Africa. Published by Wangnening, The Netherlands.

Zia-UL-Haq, M., Ahmad, S., Shad, M.A., Iqbal, S., Qayum, M., Ahmad, A., Luthria, D.L., Amarowica, R. 2011. Compositional studies of some of lentil cultivars commonly consumed in Pakistan. Pakistan J. Bot., 43: 1563-1567.

\section{How to cite this article:}

Eiman Mohammed Ali Mustafa and Hatil Hashim Al-Kamali. 2016. Proximate Composition of the Four Acacia Taxa Seeds in Central Sudan. Int.J.Curr.Res.Aca.Rev.4(4): 121-126. doi: http://dx.doi.org/10.20546/ijcrar.2016.404.014 